\title{
STRATEGI PENINGKATAN MUTU PENDIDIKAN DI SEKOLAH
}

\author{
Moh. Saifulloh \\ Zainul Muhibbin \\ Hermanto
}

\begin{abstract}
Abstrak
Banyak usaha yang telah dilakukan pemerintah untuk meningkatkan mutu pendidikan di sekolah, seperti menerbitkan Peraturan Pemerintah RI Nomor 19 tahun 2005 tentang Standar Nasional Pendidikan. Institusi pendidikan juga tidak ketinggalan dengan mengadakan kegiatan ilmiah yang dapat mengembangkan potensi guru melalui seminar, pelatihan, workshop dan lainnya secara berkelanjutan sehingga guru menjadi profesional yang mempunyai kemampuan meningkatkan mutu pembelajaran di sekolah yang pada akhirnya peningkatan mutu pendidikan akan terwujud dan menjadi kenyataan. Artikel ini membahas faktor-faktor peningkatan mutu pendidikan, unsur-unsur peningkatatan mutu pendidikan serta strategi peningkatan mutu pendidikan.
\end{abstract}

Kata kunci: mutu pendidikan.

Pendidikan merupakan faktor utama dalam pembentukan pribadi manusia. Menyadari akan hal tersebut, pemerintah sangat serius menangani pendidikan dan berusaha terus untuk peningkatan mutu pendidikan, sebab dengan sitem pendidikan yang baik diharapkan muncul generasi penerus bangsa yang berkualitas dan mampu mengadakan perubahan kearah yang lebih baik dalam kehidupan bermasyarakat berbangsa dan bernegara.

Dalam rangka meningkatkan mutu pendidikan tersebut pada tahun 2005 pemerintah mengeluarkan Peraturan RI nomor 19 tahun 2005 tentang Standar Nasional Pendidikan, peraturan ini merupakan usaha pemerintah untuk meningkatkan mutu pendidikan di Indonesia. Peraturan pemerintah tersebut berbunyi: 1 . Proses pembelajaran pada satu satuan pendidikan diselenggarakan secara interaktif, inspiratif, menyenangkan, menantang, memotivasi peserta didik untuk berprestasi aktif serta memberikan ruang yang cukup bagi prakarsa, kreatifitas dan kemandirian sesuai bakat, minat dan perkembangan fisik serta psikologis peserta didik, 2. Dalam proses pembelajaran pendidik dituntut dapat memberikan keteladanan (sebagai panutan, contoh yang baik bagi siswa), 3 .

jsh Jurnal Sosial Humaniora, Vol 5 No.2, November 2012 
Setiap satuan pendidikan melakukan perencanaan proses pembelajaran, pelaksanaan proses pembelajan, penilaian hasil pembelajaran, dan pengawasan proses pembelajaran untuk terlaksananya proses pembelajaran yang aktif dan dinamis.

Undang-undang dan Peraturan pemerintah tersebut mengindikasikan tentang pentingnya memperhatikan mutu pembelajaran guna meningkatkan mutu pendidikan di sekolah. Usaha baik pemerintah tersebut perlu ditindak lanjuti oleh institusi pendidikan sekolah baik negeri maupun swasta, dengan mengadakan kegiatan ilmiah yang dapat mengembangkan potensi guru melalui seminar, pelatihan, workshop dan lainnya secara berkelanjutan sehingga guru menjadi profesional yang mempunyai kemampuan meningkatkan mutu pembelajaran di sekolah, pada gilirannya peningkatan mutu pendidikan akan terwujud dan menjadi kenyataan.

\section{Faktor-faktor utama Peningkatan Mutu Pendidikan}

Untuk meningkatkan mutu pendidikan di sekolah, Sudarwan Danim (2007:56) mengatakan bahwa jika sebuah institusi hendak meningkatkan mutu pendidikannya maka minimal harus melibatkan lima faktor yang dominan, yaitu:

1. Kepemimpinan Kepala sekolah; kepala sekolah harus memiliki dan memahami visi kerja secara jelas, mampu dan mau bekerja keras, mempunyai dorongan kerja yang tinggi, tekun dan tabah dalam bekerja, memberikan layananyang optimal, dan disiplin kerja yang kuat.

2. Guru; pelibatan guru secara maksimal, dengan meningkatkan kompetensi dan profesi kerja guru dalam kegiatan seminar, lokakarya serta pelatihan sehingga hasil dari kegiatan tersebut diterapkan disekolah.

3. Siswa; pendekatan yang harus dilakukan adalah "anak sebagai pusat " sehingga kompetensi dan kemampuan siswa dapat digali sehingga sekolah dapat menginventarisir kekuatan yang ada pada siswa.

4. Kurikulum; adanya kurikulum yang konsisten, dinamis, dan terpadu dapat memungkinkan dan memudahkan standar mutu yang diharapkan sehingga goals (tujuan ) dapat dicapai secara maksimal. 
5. Jaringan Kerjasama; jaringan kerjasama tidak hanya terbatas pada lingkungan sekolah dan masyarakat semata (orang tua dan masyarakat) tetapi dengan organisasi lain, seperti perusahaan atau instansi pemerintah sehingga output dari sekolah dapat terserap didalam dunia kerja.

Berdasarkan pendapat diatas, dapat dijelaskan bahwa kepala sekolah dan guru mempunyai tanggung jawab besar terhadap peningkatan mutu pendidikan di sekolah. Utamanya guru, karena guru sebagai ujung tombak dilapangan (di kelas) yang bersentuhan langsung dengan siswa dalam proses pembelajaran. Oleh karena itu untuk meningkatkan mutu pembelajaran, seorang guru harus mempunyai syarat-syarat yang diperlukan dalam mengajar dan membangun pembelajaran siswa agar efektif dikelas, saling bekerjasama dalam belajar sehingga tercipta suasana yang menyenangkan dan saling menghargai (demokratis ), diantaranya :

1. Guru harus lebih banyak menggunakan metode pada waktu mengajar, variasi metode mengakibatkan penyajian bahan lebih menarik perhatian siswa, mudah diterima siswa, sehingga kelas menjadi hidup, metode pelajaran yang selalu sama( monoton ) akan membosankan siswa.

2. Menumbuhkan motivasi, hal ini sangat berperan pada kemajuan dan perkembangan siswa. Selanjutnya melalui proses belajar, bila motivasi guru tepat dan mengenai sasaran akan meningkatkan kegiatan belajar, dengan tujuan yang jelas maka siswa akan belajar lebih tekum, giat dan lebih bersemangat (Slamet, 1987 :92 ). Jika guru memiliki kompetensi tersebut, tidak mustahil peningkatkan mutu pembelajaran di sekolah dapat terwujud.

Kita yakin saat ini sudah banyak guru yang telah menguasai strategi dan model pembelajaran, namun kenyataan dilapangan kita masih banyak menjumpai guru yang dalam mengajar masih terkesan hanya melaksanakan kewajiban, banyak ceramah (telling method) dan kurang membantu pengembangan aktivitas siswa. Ia tidak menggunakan strategi dan model dalam proses pembelajaran, baginya yang penting adalah bagaimana proses pembelajaran dapat berlangsung (Hartono, 1993 :24). Realitas tersebut dapat ditemukan hampir disemua sekolah, baik di sekolah negeri maupun swasta, tidak terkecuali di madrasah atau sekolah yang berbasis Islam. Apabila hal tersebut dibiarkan maka dapat mempengaruhi 
mutu pendidikan di sekolah yang pada gilirannya akan ditemukan sekolah-sekolah yang mandul dan tidak diminati oleh siswa dan akhirnya gulung tikar.

Arif Rachman mengatakan bahwa setidaknya ada 4 hal penting yang dapat meningkatkan mutu pembelajaran dan berlanjut pada mutu pendidikan di sekolah adalah: 1. Peningkatan mutu: Sekolah harus menjadi tempat yang unggul untuk kegiatan pembelajaran, memenuhi dan menyesuaikan tuntutan dan harapan undang-undang pendidikan, visi, misi, dan tuntutan zaman, upaya sistematis dan terencana ke arah perbaikan/peningkatan mutu pendidikan, 2. Aspek peningkatan mutu: Lingkungan pembelajaran yang menyenangkan dan menantang, partisipasi aktif siswa, guru, orangtua, dan semua pemangku pendidikan, manajemen yang bertanggung jawab baik moral, mandat, manusia, dan modal, memiliki standar sekolah, baik nasional dan internasional, SDM yang akuntabel, akseptabel, dan availabel, 3. Faktor utama peningkatan mutu sekolah: Pendidik dan tenaga kependidikan yang professional, proses pembelajaran aktif yang ditunjang oleh fasilitas pembelajaran, partisipasi siswa dan orangtua siswa kepada program sekolah, supervisi secara konsisten, kontinue, dan konsekuen (pengawasan yang sehat, terhadap program, pemberdayaan manusia, dan keuangan), kemitraan (pemerintah, LS, PT, badan internasional dan lainnya), 4. Program penunjang perbaikan mutu: Kreativitas kemasan kurikulum (intrakurukuler dan ekstrakurikuler), siswa siap menghadapi program pembelajaran (kesehatan, mental, pengetahuan, kebersamaan, memahami kegunaan), keadaan keuangan yang realistis dan sumber yang terpercaya.

Berdasarkan pendapat diatas, perubahan paradigma harus dilakukan secara bersama-sama antara pimpinan, guru dan karyawan dan semua unsur pendidikan sehingga mereka mempunyai langkah dan strategi yang sama yaitu menciptakan mutu dilingkungan kerja khususnya lingkungan kerja pendidikan. Pimpinan, guru dan karyawan harus menjadi satu tim yang utuh (teamwork) yangn saling membutuhkan dan saling mengisi kekurangan yang ada sehingga target (goals) akan tercipta dengan baik.

Jadi kepala sekolah, guru, karyawan dan semua unsur pendidikan (stakeloders) mempunyai tanggung jawab terhadap peningkatan mutu 
pembelajaran di sekolah terutama guru sebagai ujung tombak di kelas karena bersentuhan langsung dengan siswa dalam proses pembelajaran. Kepemimpinan kepala sekolah dan kreatifitas guru yang professional, inovatif, kreatif, merupakan salah satu tolok ukur dalam peningkatan mutu pembelajaran di sekolah, karena kedua elemen ini merupakan figure yang bersentuhan langsung dengan proses pembelajaran , kedua elemen ini merupakan fugur sentral yang dapat memberikan kepercayaan kepada masyarakat (orang tua) siswa, kepuasan masyarakat akan terlihat dari output dan outcome yang dilakukan pada setiap periode. Jika pelayanan kepada masyarakat baik maka mereka akan sadar dan secara otomatis akan membantu segala kebutuhan yang di inginkan oleh pihak sekolah, sehingga dengan demikian maka tidak akan sulit bagi pihak sekolah untuk meningkatkan mutu pendidikan di sekolah.

\section{Peningkatan Mutu Pendidikan melalui Pembelajaran}

Syaiful Sagala (2003: 63), menyatakan bahwa pembelajaran mempunyai dua karakteristik. Pertama, dalam proses pembelajaran melibatkan proses berfikir. Kedua, dalam proses pembelajaran membangun suasana dialogis dan proses tanya jawab terus menerus yang diarahkan untuk memperbaiki dan meningkatkan kemampuan berfikir siswa, yang pada gilirannya kemampuan berfikir itu dapat membantu siswa untuk memperoleh pengetahuan yang mereka konstruksi sendiri.

Dari uraian diatas, dapat difahami bahwa proses pembelajaran yang baik dapat dilakukan oleh siswa baik di dalam maupun diluar kelas, dan dengan karakteristik yang dimiliki oleh siswa diharapkan mereka mampu berinteraksi dan bersosialisasi dengan teman-temannya secara baik dan bijak. Dengan intensitas yang tinggi serta belajar secara berkesinambungan diharapkan proses interaksi sosial sesama teman dapat tercipta dengan baik dan pada gilirannya mereka saling menghargai dan menghormati satu sama lain walaupun dalam perjalanannya mereka saling berbeda pendapat yang pada akhirnya mereka saling menumbuhkan sikap demokratis antar sesama.

Paradigma metodologi pendidikan saat ini disadari atau tidak telah mengalami suatu pergeseran dari behaviourisme ke konstruktivisme yang 
menuntut guru di lapangan harus mempunyai syarat dan kompetensi untuk dapat melakukan suatu perubahan dalam melaksanakan proses pembelajaran di kelas. Guru dituntut lebih kreatif, inovatif, tidak menjadi sumber satu-satunya proses pembelajaran (teacher centered), menempatkan siswa tidak hanya sebagai obyek belajar tetapi juga sebagai subyek belajar dan pada akhirnya bermuara pada proses pembelajaran yang menyenangkan, bergembira, dan demokratis yang menghargai setiap pendapat sehingga pada akhirnya substansi pembelajaran benar-benar dihayati.

Sejalan dengan pendapat di atas, pembelajaran menurut pandangan konstruktivisme adalah: "Pembelajaran dibangun oleh manusia sedikit demi sedikit, yang hasilnya diperluas melalui konteks yang terbatas (sempit) dan tidak sekonyong-konyong. Pembelajaran bukanlah seperangkat fakta, konsep atau kaidah yang siap untuk diambil dan diingat. Manusia harus mengkonstruksi pembelajaran itu dan membentuk makna melalui pengalaman nyata" (Depdiknas, 2003:11).

Implementasi pendekatan konstruktivisme dalam pembelajaran diwujudkan dalam bentuk pembelajaran yang berpusat pada siswa (Student Center). Guru dituntut untuk menciptakan suasana belajar sedemikian rupa, sehingga siswa bekerja sama secara gotong royong (cooperative learning). Untuk menciptakan situasi yang diharapkan pada pernyataan di atas seorang guru harus mempunyai syarat-syarat apa yang diperlukan dalam mengajar dan membangun pembelajaran siswa agar efektif dikelas, saling bekerja sama dalam belajar sehingga tercipta suasana yang menyenangkan dan saling menghargai (demokratis).

Dari pendapat di atas dapat dijelaskan bahwa, guru mempunyai tugas dan tanggung jawab yang sangat berat terhadap kemajuan dan peningkatan kompetensi siswa, di mana hasilnya akan terlihat dari jumlah siswa yang lulus dan tidak lulus. Dengan demikian, tanggung jawab peningkatan mutu pendidikan di sekolah yang dibebankan kepada guru sangat besar. Kita yakin pada saat ini banyak guru yang telah melaksanakan teori konstruktivisme dalam pembelajaran di kelas tetapi volumenya masih terbatas, karena kenyataan di lapangan kita masih 
banyak menjumpai guru yang dalam mengajar masih terkesan hanya melaksanakan kewajiban. Ia tidak memerlukan strategi, metode dalam mengajar, baginya yang penting bagaimana sebuah peristiwa pembelajaran dapat berlangsung. Ini adalah pendapat yang keliru dan haram untuk diikuti, jika tidak ingin dikatakan pemalas dan tidak profesionalis.

\section{Unsur unsur Penting dalam peningkatan mutu Pembelajaran}

Ada 2 pendekatan yang menjadi unsur penting dalam peningkatan mutu pembelajaran sekaligus mutu pendidikan di sekolah dalam sudut pandang mikro dan makro pendidikan, sebagaimana dijabarkan berikut ini:

\section{Pendekatan Mikro Pendidikan}

Yaitu suatu pendekatan terhadap pendidikan dengan indikator kajiannya dilihat dari hubungan antara elemen peserta didik, pendidik, dan interaksi keduanya dalam usaha pendidikan. Secara lengkap elemen mikro adalah: Kualitas manajemen, Pemberdayaan satuan pendidikan, Profesionalisme dan ketenagaan, Relevansi dan kebutuhan.

Berdasarkan tinjauan mikro elemen guru dan siswa yang merupakan bagian dari pemberdayaan satuan pendidikan merupakan elemen sentral. Pendidikan untuk kepentingan peserta didik mempunyai tujuan, dan untuk mencapai tujuan ini ada berbagai sumber dan kendala, dengan memperhatikan sumber dan kendala ditetapkan bahan pengajaran dan diusahakan berlangsungnya proses untuk mencapai tujuan. Proses ini menampilkan hasil belajar. Hasil belajar perlu dinilai dan dari hasil penilaian dapat menjadi umpan balik sebagai bahan masukan dan pijakan (Ety Rochaety, 2005: 8)

Secara mikro diagram alur proses pendidikan dapat dilihat pada diagram 1. Pada Diagram ini terlihat bahwa pengetahuan teori yang didapatkan dari seorang guru melalui kualitas manajemen dengan harapan tujuan pendidikan akan tercapai. Tujuan akan tercapai jika dibekali dengan bahan sehingga proses pendidikan akan terlaksana dengan baik sehingga akan menghasilkan penampilan (hasil belajar) hasil belajar dipengaruhi oleh beberapa faktor yaitu melalui 
penilaian dengan dasar kriteria penilaian, hasil dari penampilan akan dijadikan umpan balik.

Diagram 1. Alur proses pendidikan

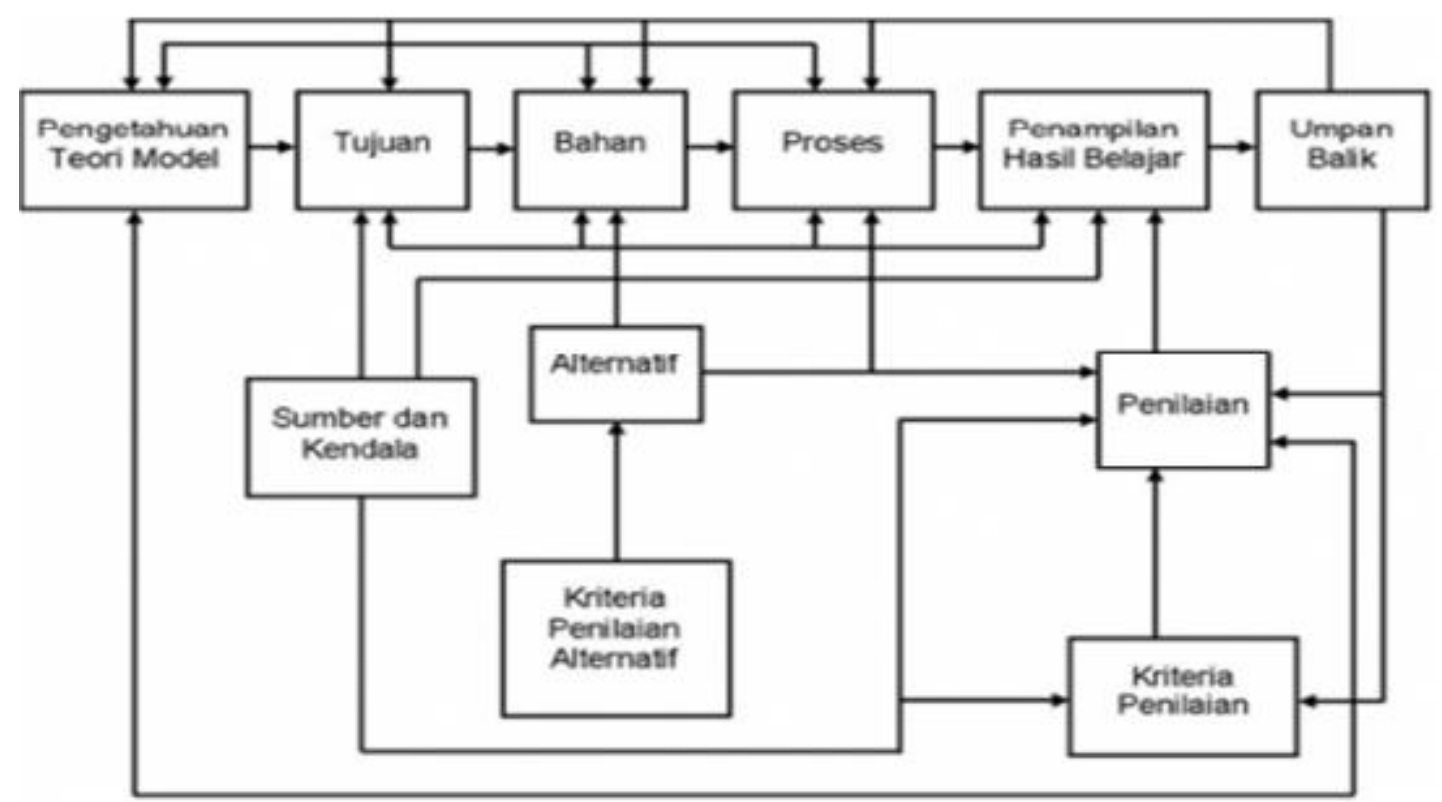

\section{Pendekatan Makro Pendidikan}

Pendekatan makro pendidikan yaitu kajian pendidikan dengan elemen yang lebih luas, yaitu dengan elemen sebagai berikut: Standarisasi pengembangan kurikulum, pemerataan, persamaan dan keadilan, standar mutu dan kemampuan bersaing. Sedangkan pendekatan makro pendidikan menyangkut berbagai hal yaitu melalui jalur pertama yaitu INPUT SUMBER - PROSES PENDIDIKAN -

HASIL PENDIDIKAN (Etty Rochaety, 2005: 8). Lebih jelasnya dapat dilihat seperti pada Diagram 2.

Input sumber pendidikan akan mempengaruhi dalam kegiatan proses pendidikan, di mana proses pendidikan didasari oleh berbagai unsur sehingga semakin siap dan semakin lengkap komponen pendidikan yang dimiliki suatu lembaga maka lembaga itu akan mampu menciptakan hasil pendidikan yang berkualitas. 
Diagram 2. Input sumber pendidikan

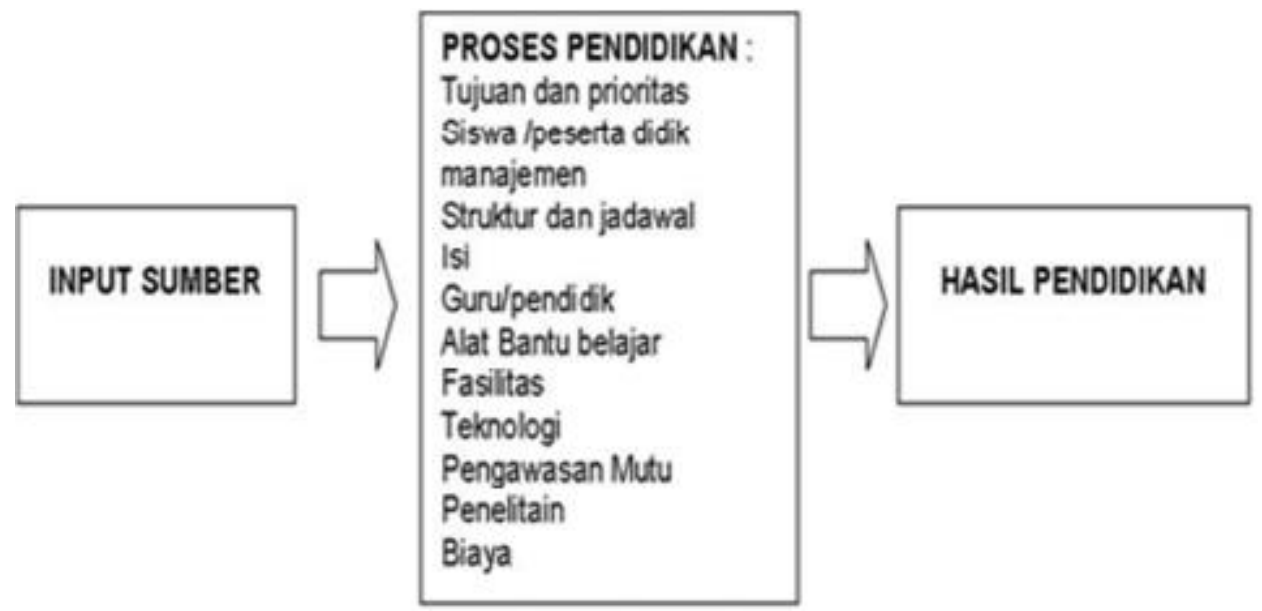

Selanjutnya Syaiful Sagala (2004: 9) menyatakan solusi manajemen pendidikan secara mikro dan makro dituangkan dalam Diagram 3.

Diagram 3. Solusi manajemen pendidikan secara mikro dan makro

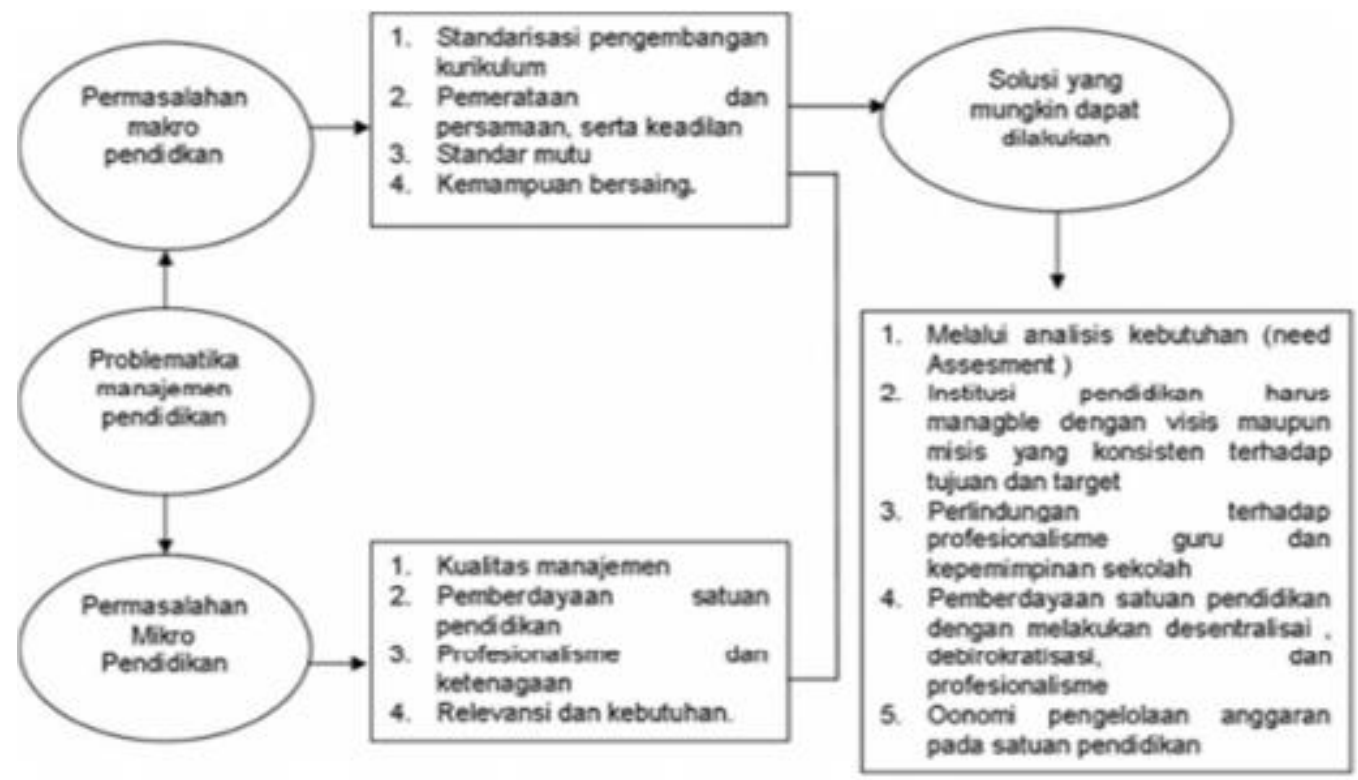

Secara umum untuk meningkatkan mutu pendidikan harus diawali dengan strategi peningkatan pemerataan pendidikan, di mana unsur makro dan mikro 
pendidikan ikut terlibat, untuk menciptakan Equality dan Equity, mengutip pendapat Indra Djati Sidi (2001: 73) bahwa pemerataan pendidikan harus mengambil langkah strategi sebagai berikut: 1 . Pemerintah menanggung biaya minimum pendidikan yang diperlukan anak usia sekolah baik negeri maupun swasta yang diberikan secara individual kepada siswa, 2. Optimalisasi sumber daya pendidikan yang sudah tersedia, antara lain melalui double shift (contoh pemberdayaan SMP terbuka dan kelas jauh), 3. Memberdayakan sekolah-sekolah swasta melalui bantuan dan subsidi dalam rangka peningkatan mutu pembelajaran siswa dan optimalisasi daya tampung yang tersedia dan 4. Meningkatkan partisipasi anggota masyarakat dan pemerintah daerah untuk ikut serta menangani penuntansan wajib belajar pendidikan dasar 9 tahun.

\section{Strategi Peningkatan Mutu Pendidikan di Sekolah}

Teori manajemen mutu terpadu atau yang lebih dikenal dengan Total Quality Management (TQM) akhir-akhir ini banyak diadopsi dan digunakan oleh dunia pendidikan dan teori ini dianggap sangat tepat dalam meningkatkan mutu dunia pendidikan saat ini. TQM didefinisikan sebagai sebuah pendekatan dalam menjalankan usaha yang berupaya memaksimalkan daya saing melalui penyempurnaan secara terus menerus atas produk, jasa, manusia, proses, dan lingkungan organisasi. Setidaknya ada sepuluh karakteristik TQM yang dianggap penting untuk meningkatkan dunia pendidikan, yaitu: 1. focus pada pelanggan (internal \& eksternal), 2. berorientasi pada kualitas, 3. menggunakan pendekatan ilmiah, 4. memiliki komitmen jangka panjang, 5. kerja sama tim, 6. menyempurnakan kualitas secara berkesinambungan, 7. Mengadakan pendidikan dan pelatihan, 8. menerapkan kebebasan yang terkendali, 9. memiliki kesatuan tujuan, 10. melibatkan dan memberdayakan karyawan (Ety Rochaety, dkk, 2005: 97).

Edward Sallis (2006: 73) menyatakan bahwa Total Quality Management (TQM) pada pendidikan adalah sebuah filsosofis tentang perbaikan secara terusmenerus yang dapat memberikan seperangkat alat praktis kepada setiap institusi 
pendidikan dalam memenuhi kebutuhan, keinginan, dan harapan para pelanggannya saat ini dan untuk masa yang akan datang.

Di sisi lain, Zamroni memandang bahwa peningkatan mutu pendidikan dapat diwujudkan dengan mengoptimalkan model The Total Quality Management (TQM) di sekolah. Teori ini menjelaskan bahwa mutu pendidikan dengan model TQM ini mencakup tiga kemampuan, yaitu kemampuan akademik, sosial, dan moral (Zamroni, 2007: 6). Teori ini juga menyebutkan bahwa mutu sekolah ditentukan oleh tiga variabel, yakni kultur sekolah, proses belajar mengajar, dan realitas sekolah. Kultur sekolah merupakan nilai-nilai, kebiasaan-kebiasaan, upacara-upacara, slogan-slogan, dan berbagai perilaku yang telah lama terbentuk di sekolah dan diteruskan dari satu angkatan ke angkatan berikutnya, baik secara sadar maupun tidak. Kultur ini diyakini mempengaruhi perilaku seluruh komponen sekolah, yaitu guru, kepala sekolah, staf administrasi, siswa, dan juga orang tua siswa. Kultur yang kondusif bagi peningkatan mutu akan mendorong perilaku warga kearah peningkatan mutu sekolah, sebaliknya kultur yang tidak kondusif akan menghambat upaya menuju peningkatan mutu sekolah.

\section{Penutup}

Dalam rangka meningkatkan mutu pendidikan di sekolah telah diupayakan melalui berbagai kegiatan penataran, seminar, pendidikan pelatihan ataupun workshop. Melalui berbagai kegiatan tersebut dikenalkan pada inovasiinovasi pembelajaran, karena inovasi adalah sebagai suatu kebutuhan. Pengembangan bahan ajar, pengembangan strategi dan metode pembelajaran, pengembangan media pembelajaran, sistem penilaian, evaluasi, dan esesmen telah menjadi menu utama dunia pendidikan, tetapi dari pengalaman empirik tampaknya upaya-upaya itu belum secara signifikan membawa perubahan dalam arti peningkatan mutu pendidikan di sekolah.

Oleh karenanya yang harus dilakukan adalah perbaikan yang berkesinambungan berkaitan dengan komitmen (Continuos quality Improvement) dan proses Continuous pross Improvement. Komitmen terhadap kualitas dimulai dengan pernyataan dedikasi pada misi dan visi bersama, serta pembedayaan 
217 - Strategi Peningkatan Mutu Pendidikan di Sekolah

semua persiapan untuk secara inkrimental mewujudkan visi tersebut. Perbaikan

yang berkesinambungan tergantung kepada dua unsur. Pertama,

mempelajari

proses, alat, dan keterampilan yang tepat. Kedua, menerapkan keterampilan baru

small achieveable project. Proses perbaikan berkesinambungan yang dapat

dilakukan berdasarkan siklus Action. Siklus ini merupakan siklus perbaikan yang

never ending, dan berlaku pada semua fase organisasi/lembaga, khusunya lembaga pendidikan.

\section{Daftar Pustaka}

Edward Sallis. 2006. Total Quality Management In Education (alih Bahasa Ahmad Ali Riyadi ). Jogjakarta : IRCiSoD

Eti Rochaety,dkk.2005 . Sistem Informamsi Manajemen Pendidikan. Jakarta bumi Aksara

Indra Djati Sidi.2003. Menuju Masyarakat Belajar. Jakarta : Logos

Muhibbin, Zainul. 2011. Problematika MTs Swasta di Surabaya Menghadapi Era

Global, Laporan Penelitian, LPPM-ITS

Republik Indonesia. (2003). Undang-Undang Nomor 20 tahun 2003

Tentang Sistem Pendidikan Nasional. Jakarta: Kloang klede Putra Timur

Rahman, Arif. 2009, Materi Workshop Peningkatan Kompetensi Mengajar melalui Konsep Metaforming, Jakarta UNJ

Sagala, Syaiful.2004. Manajemen Berbasis Sekolah \&Masyarakat. Bandaung :

alfabeta

Sagala, Syaiful.2005.Administrasi Pendidikan Kontemporer. Bandung: 
Alfabeta

Sudarwan Danim.2007.Visi Baru Manajemen Sekolah. Jakarta : Bumi Aksara

Suyadi Prawirosentono. 2007 . Filosofi Baru tentang Manajemen Mutu terpadu abad 21. Jakarta : Bumi Aksara

Tim Penyusun Kamus Besar Bahasa Indonesia..1991. Kamus Besar Bahasa Indonesia. Jakarta :Balai Pustaka

Zamroni. 2007. Meningkatkan Mutu Sekolah . Jakarta : PSAP Muhamadiyah

jsh Jurnal Sosial Humaniora, Vol 5 No. 2, November 2012 